удк 378.134.016:78

Пен Сіює

Національний педагогічний

університет імені М. П. Драгоманова

ORCID ID 0000-0001-8657-7668

DOI 10.24139/2312-5993/2020.08/468-476

\title{
ОСНОВНІ АСПЕКТИ ПІДГОТОВКИ МАЙБУТНІХ УЧИТЕЛІВ МУЗИЧНОГО МИСТЕЦТВА ДО РОЗВИТКУ ТЕМБРАЛЬНОГО СЛУХУ УЧНІВ
}

Стаття розкриває основні аспекти підготовки студентів факультетів мистецтв педагогічних університетів до розвитку тембрального слуху в практичній роботі з учнями. Виокремлено значення розвитку тембрального слуху для успішного здійснення музично-виконавської діяльності. Визначено основні аспекти розвитку тембрального слуху, а саме: системно-ціннісний, синергетичний, рефрлексивно-усвідомлений, акмеологічний та креативно-спрямований. Розроблено критерії формування тембрального слуху в майбутніх учителів музичного мистецтва у процесі музично-виконавської діяльності.

Ключові слова: тембральний слух, майбутні вчителі музичного мистецтва, основні аспекти, розвиток, учні, музично-виконавська діяльність, критерії.

Постановка проблеми. Підготовка майбутніх учителів музичного мистецтва до розвитку тембрального слуху учнів $\epsilon$ важливим завданням їх професійного становлення. Розглядаючи тембральний слух як здатність людини повноцінно сприймати всі багатогранні барви музичного мистецтва, виникає необхідність успішного формування цієї здатності в учнів, адже це $\epsilon$ передумовою їх ефективної музично-виконавської діяльності.

Аналіз актуальних досліджень. На особливе значення тембральнослухового сприйняття і самосприйняття вказували Е. Абдуллін, Л. Баренбойм, Л. Бочкарьов, І. Ванечкін, Л. Виготський, А. Готсдінер, Б. Галеев, Н. Гарбузов, А. Запорожець, В. Зінченко, Д. Кірнарська, С. Майкапар, Е. Назайкінский, С. Науменко, Я. Мільштейн, Г. Нейгауз, М. Старчеус, Б. Теплов, Г. Ципін, Ф. Шопен та ін.

Проблема розвитку тембрального слуху як відображення в особистісній свідомості складної структури музичного звуку розкрита у працях Б. Асафьєва, М. Гарбузова, Е. Курта, В. Медушевського, Є. Назайкінського, І. Страхова, М. Старчеуса, Б. Теплова, Ю. Тюліна, та ін. Учені розглядають музичні звуки, що складаються з основного тону, як домінувальні над іншими за силою звучання та обертонів, тобто призвуків, які виникають вище основного тону внаслідок ділення джерела звуку на окремі частини та взаємодії його з резонаторами.

Мета статті полягає в розкритті специфічних особливостей підготовки студентів факультетів мистецтв педагогічних університетів до розвитку 
тембрального слуху учнів, який слугує передумовою їх успішної музичновиконавської діяльності.

Методи дослідження. Для з'ясування особливостей підготовки майбутніх учителів музичного мистецтва до розвитку тембрального слуху учнів нами було використано дослідні теоретичні методи, а саме: аналіз (історико-педагогічний, логіко-теоретичний, порівняльний) психологопедагогічної та мистецтвознавчої літератури для розкриття сутності й особливостей означеного феномену та визначення основних наукових понять; синтез, абстрагування й конкретизація - для обґрунтування теоретико-практичних аспектів підготовки студентів факультетів мистецтв до розвитку тембрального слуху учнів.

Виклад основного матеріалу. 3 метою дослідження основних аспектів розвитку тембрального слуху доцільно визначити поняття «тембровий слух» у поєднанні двох складових, а саме: «тембр» і «музичний слух». Аналіз наукової літератури свідчить про те, що тембр (від фр. «timbre»; першоджерело грецьк. «tynpanon») - забарвлення, або характер звуку, якість, за якою розрізняються звуки однієї висоти і завдяки якому звучання одного інструменту або голосу відрізняються від іншого (Азарова, 2013, с. 172). Означений феномен, як фізичне явище, може бути об'єктом дослідження різних наук. Так, фізики розглядають тембр як одне з природних явищ. Учені, які вивчають музичну акустику вважають тембр однією 3 фізичних якостей музичного звуку. 3 позиції філософської науки тембр являє собою явище естетичного порядку. Психологи вивчають це явище як елемент сприйняття та музичного уявлення, тоді як музикознавці - як одну з важливих професійних якостей музиканта-виконавця.

3 позиції сучасних наукових досліджень у галузі музичної акустики, тембр визначається індикатором звукового забарвлення, що відіграє значну роль у виконавській діяльності. Тембр звуку залежить від кількості обертонів та їх відносної гучності, а також від якості звуку, вібрації тощо. Так, Ю. Тюлін розкрив поняття «тембр» як комплексне звучання обертонів, унаслідок їх поглинання основним тоном, що являє собою, у той самий час, ніби потовщене розсвічування звуку. Таким чином, виникає немовби звукове багатозвуччя, укладене в єдиний звук. За таких обставин музичний звук набуває такого звукового забарвлення, що характеризується об'ємністю та вагомістю. Звідси й виникає: звукова повнота, «округлість, насиченість, значимість та інші характерні властивості, які складають суттєву сферу виконавської музичної виразності» (Тюлін, 1977, с. 104). 
Отже, будучи звуковою якістю, за допомогою якої розрізняється звучання однієї висоти, тембр вирізняє звучання одного інструменту чи голосу від іншого. Особливе тембральне враження виникає у процесі сприйняття комплексу одночасних звуків, який аналізується слухом, під час періодичної зміни його висоти та інтенсивності (Асафьєв, 1973, с. 135). Закономірності взаємозв'язку тембру та висоти звуку отримали в музичній акустиці та психології назву вчення про два його висотні елементи.

Серед дослідників, які займалися вивченням проблеми музичної акустики, провідне місце належить М. Гарбузову. Учений приділяв велику увагу розробці проблеми тембрової виразності музичного звуку і створив теорію зонної природи тембрального слуху. Фундаментальні дослідження М. Гарбузова в сфері вивчення особливостей музичного тембру показали, що коливання «часткових тонів, які створюють характерне тембральне забарвлення звуків однієї висоти, відбувається в певній зоні, завдяки чому ми сприймаємо узагальнений тембр звуків однієї висоти різних інструментів одного типу, які звучать окремо один від одного, наприклад, тембр скрипки та фаготу. Звук, який створюється у спільному звучанні музичних інструментів одного типу, сприймається слухачами як один спільний тембр, наприклад, хорова партія чи оркестрова група» (Гарбузов, 1956, с. 60).

На основі вчення про значимість розвитку тембрального слуху (Л. Азарова, Б. Асафьєв, М. Гарбузов, В. Медушевський, Є. Назайкінський, І. Страхов, М. Старчеус, Б. Теплов, Ю. Тюлін та ін.) у музично-виконавській діяльності доцільно виокремити основні аспекти підготовки студентів факультетів мистецтв цього напрямку, а саме: системно-ціннісний, синергетичний, рефлексивно-усвідомлений, акмеологічний, креативно-спрямований.

Системно-ціннісний аспект підготовки майбутніх учителів музичного мистецтва до практичної роботи з учнями передбачає забезпечення системності в набутті знань та вмінь охоплення всієї гами тембральних відтінків та акцентує увагу на всебічності вивчення цих явищ і процесів. у контексті системно-ціннісного аспекту розгляду проблеми розвитку тембрального слуху реалізується вимога наявності різнорідних елементів та їх певної тотожності для пошуку інтеграційних зв'язків, що передбачає їх взаємне використання. Системний аспект підготовки майбутніх фахівців мистецького профілю, на думку Г. Падалки, у процесі продуктивної діяльності знаходить відображення у взаємодії трьох важливих елементів: музичноестетичного, педагогічного й виконавського (Падалка, 2008, с. 117).

Сутність та зміст системно-ціннісного аспекту підготовки майбутніх учителів музичного мистецтва до практичної роботи з учнями з розвитку 
тембрального слуху можуть бути розкриті в межах єдиної гуманістичної системи цінностей (під час збереження різноманітності їх культурних і етнічних особливостей); рівнозначність традицій і творчості, визнання необхідності вивчення й використання учінь минулого і можливості відкриття в теперішньому та майбутньому. У межах використання даного аспекту підготовки майбутніх фахівців існує можливість отримати нові результати для використання одних і тих самих елементів, забезпечується сумісність знань із різних систем завдяки загальній методології, універсальним логічним прийомам сучасного мислення за умови збереження індивідуальності використаних елементів. Основними його ознаками є глибоке розуміння природи цінностей, їх загальна значимість.

Ціннісна природа розвитку тембрального слуху майбутніх учителів музичного мистецтва дає можливість з'ясувати результативність музичновиконавського процесу, отримати відомості про стан об'єкту, забезпечити зворотний зв'язок. У процесі активної виконавської діяльності підсвідомо засвоюються цінності музичного мистецтва, основна увага спрямовується на створення яскравого художнього образу твору з використанням засобів музичної виразності. Ефективний розвиток тембрального слуху повинен ґрунтуватися не лише на реальному сприйнятті різноманітних тембрів, але й на активному використанні можливостей внутрішнього слуху студентів, тобто на інтелектуальній уяві, здатності чути музичний матеріал у його тембровому звучанні.

Синергетичний аспект підготовки майбутніх фахівців до практичної роботи з учнями передбачає існування потенціальних структур та складних цілісних систем, виявлення загальних особливостей, що підпорядковуються загальним законам виникненням цих структур, які мають можливість самоорганізовуватися. у контексті розгляду взаємозв'язку інструментального тембрального звучання 3 різними темброутворюючими структурами, що можуть впливати на характер звучання, доцільно розрізняти такі сторони сприйняття звукової палітри, як єдиної, у комплексі: тембро-регістрової, тембро-артикуляційної, темброгармонійної, тембро-фактурної, тембро-динамічної та тембро-ритмічної. Вищенаведені різновиди, безумовно, співвідносяться між собою не як самостійні поняття, а як частини або сторони одного цілого.

Традиційно в дослідженні результативності музично-педагогічного процесу фіксуються переважно показники засвоєння знань, умінь та навичок. Синергетичний аспект підготовки студентів факультетів мистецтв педагогічних університетів базується на відродженні природних, 
об'єктивно існуючих зв'язків між елементами навчального матеріалу, за рахунок чого відбувається створення, трансформація та відбір методів, форм і засобів навчання, які забезпечують сприйняття інтегративного змісту музично-виконавської діяльності (Фуллан, 2000, с. 11).

Рефлексивно-усвідомлений аспект підготовки майбутніх учителів музичного мистецтва до практичної роботи з учнями пов'язаний із осмисленням музично-педагогічної діяльності, із розвитком та реалізацією власної індивідуальності в цьому процесі. Рефлексія, певною мірою, означає самоспостереження, що спрямовує свідомість на відтворення в мовленні, думках, бажаннях інтелектуальних та емоційних почуттів, які виконавець втілює у ставленні до себе самого, до музичної діяльності (Парфентьєва, 2009, с. 75). На думку І. Зязюна, рівень розвитку рефлексивної культури особистості визначається «сукупністю здібностей, способів і стратегій для забезпечення усвідомлення й подолання стереотипів особистісного досвіду і діяльності шляхом їх переосмислення та висування інновацій для подолання тих проблемно-конфліктних ситуацій, які виникають у процесі вирішення професійних задач» (Зязюн, 2002, с. 43).

Визначаючи рівні розвитку тембрального слуху студентів факультетів мистецтв на рефлексивній основі, доцільно враховувати: усвідомлення тембру окремого звуку (інструментального або вокально-хорового); сприйняття загальних характерних особливостей музичного твору; розуміння тембральної структури музичної фактури виконуваного твору. Феномен рефлексії допомагає завдяки наявності високого ступеня розвитку уявлення відчути всі тембральні відтінки художньо-музичного образу, особливостей його музичної фактури. Для формування високого рівня рефлексії також важливе значення має інтуїція. Здатність інтуїтивно створювати художній образ та інтерпретувати його $є$ важливою ознакою професійності майбутнього вчителя музичного мистецтва.

Акмеологічний аспект підготовки студентів факультетів мистецтв педагогічних університетів до продуктивної роботи з учнями охоплює такий ступінь їх зрілості, коли «індивідуальні, особистісні та суб'єктнодіяльнісні характеристики вивчаються в єдності, в усіх взаємних зв'язках, з метою сприяння досягнення вищих рівнів розвитку» (Деркач, 2004, с. 11). 3 позиції акмеологічної освіти майбутньому фахівцю необхідно мислити професійно, творчо, компетентнісно.

У зв'язку з цим, особливого значення для майбутнього вчителя музичного мистецтва набувають цінності, що пов'язані з утвердженням своєї ролі й значення в соціальному та професійно-педагогічному середовищі; 
підвищення престижу професії вчителя музики загальноосвітньої школи; можливість успішного особистісного впливу на духовний розвиток учнів засобами музичного мистецтва. На думку А. Козир, найбільш значущими для мистецької освіти $€$ такі акмеологічні поняття, як: «творчий потенціал людини; акме - вершина життя й продуктивності діяльності; рівні та чинники продуктивної роботи, або причини, що їх обумовлюють; міра результативності професійної діяльності (Козир, 2012, с. 7).

Робота вчителя музичного мистецтва з розвитку тембрального слуху учнів в акмеологічному аспекті включає ефективне формування їх здатностей до: виявлення семантики тембральних особливостей звучання музичного твору, визначення ролі тембру як засобу музичної виразності; формулювання специфічних тембральних характеристик звучання музичного твору; виявлення стилістичних особливостей тембру; визначення специфічних особливостей структурних складових елементів тембру, а саме: метроритму, гармонії, регістрів, фактури тощо; визначення основних функцій тембрального звучання; оцінювання художньо-музичної цінності якісного виконання музичного твору.

Креативно-спрямований аспект підготовки студентів факультетів мистецтв до тембро-слухового сприйняття музичних творів потребує створення творчої атмосфери навчальних занять (Єременко, 2003, с. 13). Тому саме креативно-спрямований аспект цієї роботи $€$ найбільш ефективним, адже він сприяє підвищенню виконавсько-інструментального рівня та охоплює формування ціннісних художніх орієнтацій засобами музичного мистецтва. Розробленні музикантами, дослідниками й педагогамипрактиками концепції і рекомендації присвячені розвиткові феномену тембрального слуху обумовлюють творчу художньо-індивідуальну багатогранність будь-якого виду діяльності в галузі музичного мистецтва.

Б. Теплов розглядав креативність як сукупність тих властивостей психіки, що забезпечують продуктивні перетворення в діяльності особистості, тобто формують його обдарованість. 3 цієї позиції найбільш показовим є обговорення не «загальної та спеціальної обдарованості, а загальних та спеціальних моментів обдарованості, до яких відноситься креативність» (Теплов, 1985, с. 123). Доречно підкреслити, що здатність до креативності розвивається у процесі діяльності, з'єднується з її провідними мотивами, виявляється як прагнення до самого процесу творчості, духовного поступу, самовираження й самоствердження.

У процесі креативної діяльності активно розвивається уявлення, що сприяє розвиткові тембрального слуху, адже сприяє виникненню образів, 
що виникали у свідомості на основі минулих вражень (Гузій, 2003, с. 24). На думку $Є$. Назайкінського, уявляти означає «в думках бачити або чути. На відміну від почуттів та процесу сприймання, в уявленні відображаються не всі, але лише найбільш суттєві особливості предмету, які й закріплюються. Уявлення 3 часом набуває характеру узагальненого образу» (Назайкінський, 1972, с. 153). Музично-слухові уявлення $\epsilon$ засобом розуміння відображення змісту музичних творів, тобто яскравого відображення музичного пізнання навколишньої дійсності. 3 цієї позиції темброві уявлення - це вміння уявити собі забарвлення та характер звучання, уміння «тембрально» мислити, тобто у процесі виконавської діяльності уявити тембральні особливості одного або різних інструментів та голосів, які відповідають сутності виконуваного музичного твору.

На основі вищевикладеного, нами розроблені критерії формування тембрального слуху майбутніх учителів музичного мистецтва у процесі інструментального навчання, що дозволило в експериментальному дослідженні визначити динаміку формування означеного феномену на основі порівняння кількісних і якісних показників.

Оскільки формування тембрального слуху майбутніх учителів музичного мистецтва у процесі інструментального навчання є складним процесом із багаторівневою структурою, передбачалося, що рівні його сформованості у студентів мають відображати всі структурні компоненти досліджуваного явища, а саме: пізнавально-інформаційний, який характеризує рівень музичної ерудиції та визначається необхідністю накопичення музикознавчих та методичних знань, розвитком тембровослухових умінь та активізацією музичного мислення; когнітивноопераційний, який свідчить про обізнаність у засобах музичної виразності, наявність елементарних відомостей із ансамблевого виконання, про міру сформованості знань щодо інструментального мистецтва й бажання їх розширювати; оцінно-емпатійний, що охоплює ступінь здатності до мистецької оцінки емпатійно-вольового стану студентів факультетів мистецтв у виконавській діяльності; результативно-діяльнісний, який акумулює функціонування всієї змістово-структурної моделі формування тембрального слуху, спрямованої на творчу самореалізацію майбутніх учителів музичного мистецтва у практичній діяльності.

У висновках доцільно зазначити, що сформованість тембрального слуху майбутніх учителів музичного мистецтва у процесі інструментального навчання означає їх здатність до самостійного обґрунтованого пошуку доцільних методів удосконалення інструментально-виконавського процесу 
для отримання якісно нового власного результату музичної діяльності. Доречно зазначити, що досягнення студентом вищого рівня означає, що подальший розвиток тембрального слуху в процесі інструментального навчання стане об'єктивною необхідністю, постійним стремлінням до акмерозвитку та професійного зростання. Ефективна робота з розвитку тембрального слуху студентів факультетів мистецтв педагогічних університетів дозволяє визначати подальші тенденції розвитку їх музичного слуху та вносити відповідні корективи, що створює передумови для його постійного вдосконалення.

\section{ЛITEPATУРА}

Азарова, Л. Г., Старовойтова, О. Є. (2013). Українсько-російський та російськоукраїнський словник-довідник вокаліста. Луганськ: «ЛНУ імені Тараса Шевченка» (Azarova, L. H., Starovoitova, O. Ye. (2013). Ukrainian-Russian and Russian-Ukrainian vocabulary guide. Luhansk: Taras Shevchenko LNU).

Асафьев, Б. В. (1973). Избранные статьи о музыкальном просвещении и образовании. л.: Музыка (Asafiiev, В. V. (1973). Selected Articles on M usic Education. L.: M usic).

Гарбузов, Н. А. (1956). Зонная природа тембрового слуха. М.: Музыка (Harbuzov, N. А. (1956). Zonal nature of timbre hearing. M .: Music).

Гузій, Н. В. (2003). Креативно-аксіологічні засади інтегративних складових педагогічного професіоналізму. Творча особистість учителя: проблеми теорії і практики: зб. наук. праць. К.: Вид-во НПу (Huzii, N. V. (2003). Creative-axiological principles of integrative components of pedagogical professionalism. Creative personality of the teacher: problems of theory and practice. K.: Published by Drahomanov NPU).

Деркач, А. А. (2004). Акмеологические основы развития профессионализма. М.: Изд-во Московского психолого-социального ин-та; Воронеж: НПО «МОДЭК» (Derkach, A. A. (2004). Acmeological foundations for the development of professionalism. M.: Publishing house of the M oscow Psychological and Social Institute; Voronezh: NPO MODEK).

Єременко, О. В. (2003). Теорія і методика розвитку музичного сприймання в учнів основної школи. Суми (Yeremenko, O. V. (2003). Theory and methods of development of musical perception in primary school students. Sumy).

Зязюн, І. А. (2003). Педагогіка і психологія професійної освіти: результати досліджень і перспективи. K.: КПЕК (Ziaziun, I. A. (2003). Pedagogy and psychology of vocational education: research results and prospects. K.: KPEK).

Козир, А. В., Федоришин, В. І. (2012). Вступ до акмеології мистецької освіти. К.: НПУ імені М.П. Драгоманова (Kozyr, А. V., Fedoryshyn, V. I. (2012). Introduction to the acmeology of art education. K.: Drahomanov NPU).

Назайкинский, Е. В. (1972). О психологии музыкального восприятия. М.: Музыка (Nazaikinskyi, E. V. (1972). On the psychology of musical perception. M .: M usic).

Падалка, Г. М. (2008). Педагогіка мистецтва (Теорія і методика викладання мистецьких дисциплін). К.: Освіта Україна (Padalka, Н. М. (2008). Pedagogy of art (Theory and methods of teaching art disciplines). K.: Education Ukraine).

Парфентьєва, І. П. (2009). Розвиток мистецької рефлексії як основного компонента артпедагогічної підготовки майбутніх учителів музики. Педагогіка, В. 95, Т. 105. Миколаїв: чдУ імені Петра Могили (Parfentieva, І. Р. (2009). Development of artistic reflection as the main component of art-pedagogical training of future music teachers. Pedagogy, Issue 95, Vol. 105. M ykolaiiv: Petro M ohyla BSCU). 
Теплов, Б. М. (1985). Психология музыкальных способностей. М.: Педагогика (Teplov, B. M. (1985). Psychology of M usical Ability. M.: Pedagogy).

Тюлин, Ю. Н. (1977). Учение о музыкальной фрактуре и мелодической фигурации. Yacmь 2. М.: Музыка (Tiulin, Yu. N. (1977). The doctrine of musical texture and melodic figure. Part 2. M oscow: Music).

Фуллан, М. (2000). Сили змін: вимірювання глибини освітніх реформ. Львів: Літопис (Fullan, M. (2000). Change forces: measuring the depth of educational reforms. Lviv: Litopys).

\section{PEЗЮME}

Пен Сиюе. Основные аспекты подготовки будущих учителей музыкального искусства к развитию тембрового слуха учеников.

Статья раскрывает основные аспекты подготовки студентов фракультетов искусств педагогических университетов к развитию тембрального слуха в практической работе с учениками. Определено значение развития тембрального слуха для успешного осуществления музыкально-исполнительской деятельности. Раскрыты основные аспекты развития тембрального слуха, а именно: системноценностный, синергетический, рефлексивно-осознанный, акмеологический и креативно-направленный. Разработаны критерии формирования тембрального слуха у будущих учителей музыкального искусства в процессе музыкальноисполнительской деятельности.

Ключевые слова: тембральный слух, будущие учителя музыкального искусства, основные аспекты, развитие, ученики, музыкально-исполнительская деятельность, критерии.

\section{SUMMARY}

Pen Syue The main aspects of training future teachers of musical art for the development of pupils' timbre hearing.

The article reveals the main aspects of training students of the faculties of arts of pedagogical universities for the development of timbre hearing in practical work with students. The importance of the development of timbre hearing for the successful implementation of musical performance is highlighted.

The main aspects of the timbre hearing development are determined, namely: systemvalue, synergetic, reflective-conscious, acmeological and creative-directed. The criteria for the formation of timbre hearing in future teachers of musical art in the process of musical performance have been developed. The system-value aspect of preparation of future musical art teachers for practical work with students provides for the system of acquiring knowledge and skills to cover the whole range of timbre shades and emphasizes the importance of these phenomena. The synergetic aspect of preparation of future specialists for practical work with students presupposes the existence of potential structures and complex integral systems, identification of general features that are subject to the general laws of origin. The reflexively conscious aspect of preparing future teachers of musical art for practical work with students is connected with the comprehension of music-pedagogical activity, with the development and realization of one's own individuality in this process. The acmeological aspect of preparing students of art faculties of pedagogical universities for productive work with students covers the degree of their maturity, when individual, personal and subject-activity characteristics are studied in unity, in all interrelations, in order to promote higher levels of development. Creativeoriented aspect of preparing students of art faculties for timbre-auditory perception of musical works requires creation of a creative atmosphere of educational activities.

Key words timbre hearing, future teachers of musical art, main aspects, development, students, musical performance, criteria. 